\title{
Kimberlites and Related Rocks: Tracers of the Mantle and Geodynamic Processes
}

\author{
Ashutosh Pandey, Wadia Institute of Himalayan Geology, Dehradun - 248 001, India
}

E-mail:ashutosh@wihg.res.in

Received: 17 October 2021 / Revised form Accepted: 21 October 2021

(C) 2022 Geological Society of India, Bengaluru, India

Kimberlites are volatile-rich deep mantle-derived rocks that often contain diamonds. Kimberlites and related rocks such as lamproites and lamprophyres along with their entrained xenoliths are known to geologists for their fidelity in probing Earth's mantle. Their relevance in comprehending the nature and evolution of mantle is well documented. These mantle-derived, volatile-rich rocks with exotic mineralogy and geochemistry are associated both with the cratonic and off-cratonic regions and are linked with amalgamation as well as the break-up of supercontinents such as Columbia, Rodinia, or Gondwana-Pangea in the Earth's history. In my talk on "Kimberlites and related rocks: tracers of the mantle and geodynamic processes", I shall focus on geochemical fingerprinting of the mantle sources of these rocks from the Eastern Dharwar Craton and their significance in the context of the geodynamic evolution of the southern Indian shield during Mesoproterozoic.

The southern Indian shield hosts numerous Mesoproterozoic ( 1.1 Gyr) kimberlites, lamprophyres, and lamproites in a corridor that is aligned almost parallel to the Eastern Ghats Mobile Belt. The kimberlites of the Eastern Dharwar Craton are clustered in four kimberlite fields- the Narayanpet in the north, the Raichur and the Tungabhadra in the centre, and the Wajrakarur kimberlite field in the south. The kimberlites of the WKF occur in five distinct clusters- the Wajrakarur, the Lattavaram, the Chigicherla, the Kalyandurg and the Timmasamudram. Interestingly, some shoshonitic lamprophyre dykes characterized by the presence of olivine, biotite, zoned clinopyroxene set in feldspathic groundmass are exposed within the Lattavaram cluster of the Wajrakarur kimberlite field. These potassic dykes show geochemical traits similar to ocean island basalts and are geochemically and isotopically distinct from the co-eval and co-spatial kimberlites. It is suggested that the Wajrakarur kimberlites were generated from a deeper slightly depleted to chondritic mantle compared to the shallower enriched lithospheric mantle source for the shoshonitic lamprophyres (Pandey et al., 2017).

It is well known that lithium isotopes are potential geochemical tools to understand crust-mantle interaction. Recent lithium isotopic study on the Mesoproterozoic kimberlites, lamproites and lamprophyres from the Eastern Dharwar Craton has highlighted the presence of a component with a heavy $\mathrm{Li}$ isotope signature $\left(\delta^{7} \mathrm{Li}\right.$ up to $8.7 \%$ ) in the kimberlites similar to an ancient altered oceanic crust (Krmíèek et al., 2021). The cratonic lamproites and lamprophyres, on the other hand, show variable $\delta^{7} \mathrm{Li}$ values indicative of a dominant contribution from the heterogeneous lithospheric mantle. Similar rock types from off-cratonic regions such as Variscan and Alpine-Himalayan orogenic belts are characterized by conspicuous lighter lithium isotopic signature ( $\delta^{7} \mathrm{Li}$ as low as $-9.5 \%$ ) revealing the involvement of an evolved crustal material in their mantle source, which is missing in the source of cratonic kimberlites, lamproites and lamprophyres from southern India.

A synthesis of the existing radiometric ages of the $\sim 1.1 \mathrm{Gyr}$ kimberlites, lamproites, and ultramafic lamprophyres from the Eastern Dharwar Craton and the Bastar Craton show that the kimberlites and associated magmas were emplaced for a longer duration (ca. $130 \mathrm{Myr}$ ) than previously thought in the Indian shield during the Mesoproterozoic and sampled distinct mantle source regions. The kimberlites and ultramafic lamprophyre are characterized by slightly depleted to chondritic $\mathrm{Nd}$ isotopic ratios revealing their origin at deeper sublithospheric regions, whereas the lamproites essentially show an enriched $\mathrm{Nd}$ isotopic signature suggesting their derivation from an enriched sub-continental lithospheric mantle. The absence of linear age progression and prolonged magmatic activity compared to the time span of coeval large igneous provinces (the Umkondo, the Keweenawan, and the Warakurna) are important limitations for a plume model earlier proposed for the emplacement of these kimberlites and related magmas (Pandey and Chalapathi Rao, 2020). In this regard, exploring alternative models for the origin of kimberlites and related rocks in the southern Indian shield is required.

\section{References}

Krmíèek, L., Magna, T., Pandey, A., Chalapathi Rao, N.V., Kynicki, J. (2021) Lithium isotopes in kimberlites, lamproites and lamprophyres as tracers of source components and processes related to supercontinent cycles. Geol. Soc. London Spec. Publ., no.513. doi: 10.1144/SP513-2021-60

Pandey, A., Chalapathi Rao, N.V. (2020) Supercontinent transition as a trigger for $\sim 1.1 \mathrm{Gyr}$ diamondiferous kimberlites and related magmatism in India. Lithos, v.370-371, 105620. doi: 10.1016/ j.lithos.2020.105620

Pandey, A., Chalapathi Rao, N.V., Chakrabarti, R., Pandit, D., Pankaj, P., Kumar, A., Sahoo, S. (2017) Petrogenesis of a Mesoproterozoic shoshonitic lamprophyre dyke from the Wajrakarur kimberlite field, eastern Dharwar craton, southern India: Geochemical and Sr-Nd isotopic evidence for a modified sub-continental lithospheric mantle source. Lithos, v.292-293, pp.218-233. doi:10.1016/ j.lithos.2017.09.001 